\title{
Competing socio-technical narratives in times of grid capacity challenges: the representative case of Sweden
}

\author{
Frans Libertson* ${ }^{*}$ (D)
}

\begin{abstract}
Background: Around the globe the electricity sector is strikingly similar, as regardless of nation it is structured around centralized large-scale power production. However, these centralized systems are currently experiencing operational problems related to climate change, energy security and aging grid infrastructures. In Sweden, the lack of investment and maintenance of the grid have created bottlenecks in certain regions, which are now facing an electricity shortage. This capacity crisis has received the attention of the media and generated a debate around the future trajectory of the electricity system.
\end{abstract}

Results: The purpose of this study is to analyze the ongoing media discourse in Sweden to determine whether there is a dominant narrative in the debate and its potential implications. The findings indicate that the government is unanimously held accountable for the electricity shortage and that there is a strong inclination toward a centralized electricity system as a solution.

Conclusion: The results indicate that the dominating centralized narrative, should it receive too much traction, might create a technological lock-in and result in overlooking the many advantages of a decentralized electricity system. Ultimately, this might give rise to an outdated electricity system that stalls its transformation toward a more sustainable path.

Keywords: Socio-technical narratives, Electricity system, Centralization, Decentralization, Technological lock-in, Transition

\section{Introduction}

Around the globe the electricity sector is strikingly similar, as regardless of nation it is structured around centralized large-scale power production [1,2]. However, these centralized systems are currently experiencing operational problems related to climate change, energy security, aging grid infrastructures, and regional challenges [1]. The pressing conditions under which the electricity sector is forced to operate have resulted in an increased interest in alternatives, such as decentralized electricity

${ }^{*}$ Correspondence: frans.liberston@iiiee.lu.se International Institute for Industrial Environmental Economics (IIIEE), Lund University, Box 196, 22100 Lund, Sweden systems and renewable energy generation [3, 4]. The process of decentralization is regarded by some as part of the energy transition that would render the electricity system more capable of addressing future challenges. Although not without its challenges [5], this transformation of the electricity system is essential for transitioning to an energy-efficient low-carbon economy [6]. Hojčková et al. [1] demonstrated that such a transition is viable through multiple electricity system architectures. However, the different system structures influence societal actors in disparate ways, and they all come with various benefits and issues. Each system structure also holds a corresponding narrative that conveys its vision of energy future. The focus of this study is to decipher the ongoing original author(s) and the source, provide a link to the Creative Commons licence, and indicate if changes were made. The images or other third party material in this article are included in the article's Creative Commons licence, unless indicated otherwise in a credit line to the material. If material is not included in the article's Creative Commons licence and your intended use is not permitted by statutory regulation or exceeds the permitted use, you will need to obtain permission directly from the copyright holder. To view a copy of this licence, visit http://creativecommons.org/licenses/by/4.0/. The Creative Commons Public Domain Dedication waiver (http://creativeco mmons.org/publicdomain/zero/1.0/) applies to the data made available in this article, unless otherwise stated in a credit line to the data. 
media discourse in Sweden concerning the challenges of the nation's electricity system and to outline the narratives of the debate.

Sweden constitutes a representative case in the sense that the nation has a centralized energy system that is becoming increasingly challenged by decentralized ideas. Like many other electricity systems, the Swedish electricity grid is subject to several challenges, such as the increasing electrification of different sectors and the introduction of intermittent renewable energy generation [7-9]. The steady increase in urbanization [10], together with the electrification of the transport sector [11] and the establishment of data centers for cloud services [12, 13], puts additional pressure on the grid.

Concurrently, recent decades have seen negligence in maintaining and modernizing the Swedish electricity grid. This neglect has resulted in network bottlenecks in certain regions where the electricity supply no longer can be guaranteed, according to The Swedish National Grid [14]. Furthermore, the baseload in Swedish electricity production constitutes $40 \%$ hydropower and $40 \%$ nuclear power [15], and although no politically mandated phaseout of nuclear power exists, current regulations have rendered nuclear power production unprofitable, which has resulted in premature decommissioning [16]. In essence, the constrained electricity supply is struggling to meet the rapidly increasing demand.

However, the risk of an electricity shortage is not primarily a matter of production, but an issue of power. In fact, Sweden has an electricity surplus and exports electricity to neighboring countries yearly [15]. But a majority of Sweden's electricity production is located in the north, whereas most of the consumption takes place in the south. When the consumption increases, the electricity grid simply cannot sustain the supply of power as the electricity must be transmitted from north to south [17]. In short, the electricity shortage is primarily an issue of lack of capacity.

Estimations predict that during certain hours of a few days of the year the system will have difficulties in sustaining the electricity supply. If no action is taken, Sweden may face an electricity shortage [14]. An improvement of the electricity system is of the essence, not only in regard to energy security, but also on grounds of the Swedish Climate Policy Action Plan, in which Sweden has pledged to a $100 \%$ share of renewables in energy production by 2040 [15]. In other words, the Swedish electricity grid faces a short-term and a long-term challenge: remedying the electricity supply's dire situation (short-term) and executing the Swedish Climate Policy Action Plan (longterm). These challenges require political collaboration and insightful knowledge to shape effective policies. Furthermore, building a sustainable electricity system for the twenty-first century requires collaboration between public and private actors on national, regional and local levels [18]. However, an agreement appears to be far out of reach, as no shared vision of how to concretize the Climate Policy Action Plan exists [15].

\section{Justification for research}

The focus of this study is to decipher the ongoing media discourse in Sweden concerning the electricity shortage and its proposed solutions (short-term challenge), and thereby also discerning the related pathways for Sweden's energy future (long-term challenge). In doing so, the study aspires to answer the question: how has the future of Sweden's electricity system in general and the electricity shortage in particular been discussed and envisioned within Swedish newspapers over the last decade? By answering these questions this study will also contribute to the growing body of knowledge of applied socio-technical narrative theory [19] on real cases, such as the US and South Korea [20], India [21], Norway [22], Germany [23], Poland [24], Ireland [25] and the UK [26]. In addition, the paper will also add to the knowledge on how media influence the public understanding of energy consumption, which has been identified as research with a high priority within social science [27].

There are several reasons for analyzing media discourses through the lens of socio-technical narratives. Media discourses are instrumental in the process of shaping and reproducing narratives and future visions. Analyzing media discourses thus provides insight into how common future visions are being created by the contemporary debate $[19,26]$. Media discourses constitute an arena of debate for both public and private actors who want to gain control over the popular interpretation of reality [26]. The future visions and beliefs of narratives are instrumental to political strategies, which if successful will materialize the narratives [26, 28, 29]. The focal point of this paper is to analyze narratives of the media discourse around electricity shortage as a communicative tool, to understand the ways in which the problem is outlined, the ramifications should the problem go unresolved, and how the proposed remedy should be interpreted.

This study proceeds as follows: the subsequent section outlines the theoretical framework of socio-technical narratives that has been applied to deconstruct the media discourse into different narratives. "Methodology" section provides the methodological background of the study. "Results" section describes the two identified narratives and their depiction of the root cause of the electricity shortage, how the problem is best solved, and who should be held accountable for its occurrence. The narratives also hold visions of Sweden's energy future that to a 
large extent shape each narrative's understanding of the electricity shortage and its resolution. "Discussion" section, elaborates on some of the implications that these narratives have for energy policies. "Conclusion" section provides some final remarks about the study and propositions for future avenues of research.

\section{Socio-technical narratives}

Narratives constitute verbal social constructions [30] that are conveyed as storylines comprising beginnings that outline the problem, middles that elaborate on the ramifications should the problem go unresolved, and ends that propose the remedy [21, 23, 31-33]. Narratives commonly portray simplifications of complex issues that aspire to aid and guide their adherents and render the problems more conceivable when faced with difficult decision-making [21, 23, 31]. In that sense, narratives provide meaning to everyday life as they are utilized to make sense of reality and the order of things. Hence, narratives do not only convey how the past and the present should be interpreted, but may also hold visions of desirable futures, thus linking the past and the present with the future $[20,29,34]$. As narratives are social constructs, they convey not only facts and objects for consideration, but also the ways in which these facts and objects should be understood and interpreted. Furthermore, narratives also convey that which is desirable and express value judgements within a culture [22, 35], and are thus also instrumental in upholding value systems [33]. In doing so, narratives to some extent disregard the objective truth, as their success is much more propelled by their "internal logic" and "rhetorical persuasiveness" for their audience rather than any empirical evidence [31].

Narratives attribute roles to their involved actors, in which they are depicted as heroes, villains or victims. The hero is the protagonist of the storyline who calls attention to a problem and its potential consequences. Not seldomly, the hero also holds the (sole) solution to the problem. The villain is the antagonist of the storyline, who the hero claims is to be blamed for the problem. The victims are those harmed by the villain's actions or inactions and worthy of public attention. Additionally, the heroes and villains each have followers, that is to say, groups of allies and opponents of their cause [21, 23, 30, 35]. By assigning roles to the actors, the construct of the storyline allows for attributing blame, accountability and responsibility to certain actors and for legitimizing specific actions [21, 23].

By analyzing policy debate thorough the lens of narratives, it is possible to distinguish whether and how policymaking is influenced by narratives [21, 35]. Intentionally or not, political narratives are designed to maneuver their recipients toward a certain stance, preference or opinion in policy issues $[21,23,30]$. This is achieved by formulating the policy problem within a certain framework only to then frame the solution on the same premise. Similarly, the narrative framework also deliberately excludes alternative pathways [35]. Ultimately, the goal of the political narrative is to frame the problem so that the presented solution is favored and appears in the interest of the public [30].

Narratives are normalizing in the sense that the narrator is perceived to know the true nature of things. Beliefs are presented as facts and diverging opinions are dismissed as fiction or outright lies [35]. By fostering a shared vision, political narratives can call for action and policy decisions, legitimize new investments or reinvestments in infrastructure, and promote certain technological solutions and strategies [22]. As different groups of actors have diverging perceptions of the order of things, competing narratives can exist in tandem [23]. However, over time certain narratives evolve and manifest into pathways while others become marginalized and are never influential [32].

This study will scrutinize the media discourse through the lens of narratives to understand how the Swedish electricity system is portrayed and envisioned as a sociotechnical system.

\section{Methodology}

The data for this study comprise articles published in Swedish newspapers. The sample was designed to include news coverage and debate articles from national newspapers as well as local papers from the regions of Stockholm, Gothenburg, Malmö and Uppsala. This scope was justified by the fact that these are the largest urbanized regions in Sweden and the regions where the electricity shortage is the most pressing. Furthermore, local newspapers in other regions commonly reiterate what is being published in the major newspapers. The articles were found using the keywords "power deficit", "electricity shortage" and "capacity deficit" (in Swedish: "effektbrist", "elbrist" and "kapacitetsbrist"). The initial sample comprised 1083 articles published during the 10-year period of 2010 to 2020. The total number of articles was reduced to 312 during the analysis because of duplicates, reiterations and unrelated content. The sample constituted eight daily newspapers that are considered to jointly represent the full political spectrum; the national news bureau; and a weekly magazine focused on reporting news from industrial sectors such as energy, transport, and life science.

During the analysis, the data were categorized using qualitative analysis according to either a centralized or a decentralized narrative. The reason for this dichotomous categorization was due to the nature of the debate, 
which is rather polarized. It should be noted, however, that the categorization also resulted in the loss of a certain nuance. The definitions of the narratives and what constitutes a centralized vis-à-vis a decentralized electricity system was derived from the typology of Lönnroth et al. [36]. The articles were classified as adhering to either a centralized or decentralized narrative based on the nature of their argument, how the problem was framed, or how the solutions were presented. These indicators could either be implicitly or explicitly expressed in the articles. The articles were also coded according to a set of keywords that expressed their contents. In addition to the keywords, the articles were also coded according to the actors participating in the debate, the actors mentioned in the debate, and the question of accountability .

\section{Results}

\section{Centralized vs decentralized electricity systems}

The hallmarks of centralized electricity systems are large production facilities that cater to the electricity demand of consumers in a large geographical area. In general, the electricity is generated in power plants at distant locations and transmitted to the load center via long transmission lines and large distribution networks [37, 38].
Quezada et al. [39] refer to centralized electricity systems as large technical systems. Large technical systems are characterized by a strong coupling among the system units, which renders the system structure rigid. The strong links imply that the changing of one unit must take the entire pre-existing structure into consideration, and the introduction of new technology is particularly complex [40]. Ultimately, this rigidity affects the development of the systems as it pushes the system into a certain trajectory [41-43].

Recent scholars have stated that no common definition for decentralized electricity systems exists [44, 45]. However, there have been attempts to put forward encompassing interpretations. One of the most significant definitions describes decentralized electricity systems as networks where the "electric power source[s] are connected directly to the distribution network or on the customer side of the meter" [46]. Other definitions emphasize the more democratic aspects of such systems, such as the more equal control over and distribution of electricity production and conversion facilities, as well as the "reallocation of decision-making, expertise, ownership and responsibility" [37]. In research, a number of related (albeit not fully synonymous) terms

Table 1 Typology of centralized and decentralized electricity generation

\begin{tabular}{|c|c|c|}
\hline & Centralized electricity system & Decentralized electricity system \\
\hline Electricity market & Few large actors & Several smaller actors \\
\hline Investment capital & $\begin{array}{l}\text { Large sums of investment capital are invested in one or } \\
\text { a few actors }\end{array}$ & $\begin{array}{l}\text { Large sums of investment capital are divided between } \\
\text { several actors on all levels of society (micro-, meso- and } \\
\text { macro-level) }\end{array}$ \\
\hline Facilities & $\begin{array}{l}\text { A few large power plants that require specialists to } \\
\text { operate }\end{array}$ & Several smaller facilities that require generalists to operate \\
\hline Accountability (centralized/local) & Accountability is centralized & $\begin{array}{l}\text { Accountability is decentralized and divided between } \\
\text { local, regional and national institutions and actors }\end{array}$ \\
\hline Accountability (public/private) & Government and a few large actors & Municipal institutions, neighborhoods and local facilities \\
\hline Employment & Requires highly qualified specialists; technocratic elite & $\begin{array}{l}\text { Requires generalists capable of adapting local energy } \\
\text { sources to local needs }\end{array}$ \\
\hline Electricity system & $\begin{array}{l}\text { Dominates the preconditions for its surroundings and } \\
\text { the environment }\end{array}$ & $\begin{array}{l}\text { Is dominated by the preconditions of its surroundings } \\
\text { and environment }\end{array}$ \\
\hline
\end{tabular}

Table 2 Number of articles divided according to narrative with their respective five most common keywords and the number of articles that mention them

\begin{tabular}{lll}
\hline & Centralized narrative & Decentralized narrative \\
\hline Number of articles & 294 & Nuclear power production (133) \\
Five most common keywords & Energy policy (86) & Flexibility (21) \\
& Impeded growth (67) & Renewable energy (14) \\
& Transformation (44) & Tration (17) \\
\hline
\end{tabular}


Table 3 The roles attributed by the centralized and the decentralized narrative

\begin{tabular}{|c|c|c|}
\hline & Centralized narrative & Decentralized narrative \\
\hline Problem & $\begin{array}{l}\text { The decommissioning of nuclear power production } \\
\text { Counterproductive taxation } \\
\text { Neglected national power grid } \\
\text { Intermittent power production cannot replace controlled power } \\
\text { production } \\
\text { Increasing electrification }\end{array}$ & $\begin{array}{l}\text { Outdated electricity system } \\
\text { Climate change creates new conditions and requires improved } \\
\text { systems } \\
\text { Increasing electrification }\end{array}$ \\
\hline Consequence & $\begin{array}{l}\text { Impeded growth (national and regional) } \\
\text { Loss of job opportunities } \\
\text { Increased electricity prices } \\
\text { Blackouts } \\
\text { Impaired sustainable transformation }\end{array}$ & $\begin{array}{l}\text { Unachieved climate goals } \\
\text { Impaired sustainable transformation }\end{array}$ \\
\hline Solution & $\begin{array}{l}\text { Halt the decommissioning of nuclear power production } \\
\text { Build next-generation nuclear power plants } \\
\text { Remove counterproductive taxation } \\
\text { Improve national infrastructures and international connections }\end{array}$ & $\begin{array}{l}\text { Decentralization } \\
\text { Flexible electricity system } \\
\text { Smart grids } \\
\text { Renewable energy production } \\
\text { Local energy production } \\
\text { Collaboration }\end{array}$ \\
\hline Hero & The state & The society \\
\hline Villain & The government & $\begin{array}{l}\text { The government is held accountable for not accommodating } \\
\text { collaborations accordingly, but emphasis is also on the indi- } \\
\text { vidual responsibility of every stakeholder }\end{array}$ \\
\hline Victim & $\begin{array}{l}\text { Businesses and industries } \\
\text { Local energy companies } \\
\text { Citizens }\end{array}$ & Future society \\
\hline Supporters & $\begin{array}{l}\text { The government } \\
\text { Umbrella business organizations } \\
\text { The industry } \\
\text { Media } \\
\text { The Moderate Party }\end{array}$ & $\begin{array}{l}\text { Academia } \\
\text { Energy consultants } \\
\text { Umbrella energy organizations } \\
\text { NGOs } \\
\text { The Swedish Green Party }\end{array}$ \\
\hline
\end{tabular}

are also used, such as "distributed generation", "embedded generation" and "dispersed generation" [44, 46, 47].

For the sake of this analysis, a derivation of the typology by Lönnroth et al. [36] is used (Table 1). According to this typology, a centralized electricity system is characterized by a small number of very large production facilities, whereas a decentralized electricity system is distinguished by a larger number of small-scale and local facilities [36]. Furthermore, a centralized system constitutes stability and controllability while a decentralized system symbolizes flexibility and intermittent energy production. Thus, a centralized system is sometimes equated with nuclear power and large-scale conventional energy production, whereas a decentralized system might comprise solar and wind power as well as other forms of renewable energy production [36]. As might be expected, the two different systems are to a certain extent each other's antithesis [37]. However, this does not entail that they cannot be combined or co-exist. It should also be noted that centralized and decentralized designs may refer to both technologies and organizational structure, and the former does not necessitates the latter and vice versa [44].
In total, 312 newspaper articles were analyzed. The narratives reflected in the discourse have been divided into two categories: the centralized narrative and the decentralized narrative (Table 2). As the issue of the electricity shortage (short-term challenge) to some extent overlaps the issue of executing the Swedish Climate Policy Action Plan (long-term challenge), the two narratives expressed solutions to both, albeit with different emphasis. As the centralized narrative promotes the current centralized constitution of the electricity system, it emphasizes solutions to the short-term challenge that also preserve the system's composition, and thereby omitting to present a distinct future vision as it opines that the future system should resemble the present. In contrast, the decentralized narrative promotes solutions that are yet to be realized, and thereby also expressing more distinguished future visions for the electricity system.

Close to $90 \%$ of these articles expressed a centralized narrative, either explicitly or implicitly (see Table 3 for a summary of the narratives' contents.) The actors participating in the media discourse were clustered into categories and ranked according to the number of times they participated and the number of times they were 
mentioned. The most prominent categories were in the following order (participation/mentioning): energy companies (150/197), public organizations (90/197), political parties (85/45), users (55/56) and media (39/0).

\section{The centralized narrative}

Swedish nuclear power production has played a significant role in the nation's transition to a rich welfare state. It has allowed for a stable and controllable source of energy, which has enabled Sweden to provide for its energy-intense industries whilst also decoupling its economic growth from its $\mathrm{CO}_{2}$ emissions. In doing so, nuclear power has come to symbolize stability and thereby also economic safety [48]. As might be expected, the symbology of nuclear power production is highly prominent in the centralized narrative. It is therefore not surprising that the proponents of this narrative blame the electricity shortage on the premature decommissioning of nuclear power production.

Nuclear power has served Sweden extraordinary well. As I see it, its significance is constantly underestimated, and in accordance with our current strategies nuclear power will play a prominent role for decades to come. (Miljarder pumpas in i kränkraften, Dagens Industri)

The centralized narrative is to some extent worried about the loss of control over the electricity supply. The genesis of the electricity shortage, according to this narrative, is the decrease in (controllable) electricity production. Contemporary Swedish energy policies have rendered nuclear power production unprofitable, and it is now facing a premature decommissioning. Yet other policies are threatening the buoyancy of local combined heat and power production facilities, some of which have already ceased operation. Taken together, the electricity shortage is primarily perceived as a result of a decrease in supply. Proponents of the centralized narrative are skeptical of the idea that wind and solar power can replace nuclear-generated electricity. The underlying argument is that due to its intermittent nature and meager scale, renewable energy production cannot be a substitute for current controllable energy forms. Thus, the superiority of nuclear power in this regard is often heard in the debate:

That which distinguishes nuclear power from other environmentally friendly energy sources are the possibilities of large-scale production. (Sverige behöver bygga moderna kärnkraftverk, Dagens Industri)
The current energy system is stable thanks to the baseload provided by nuclear power. (Väderberoende energi kan ej ersätta känrkraft, Lppsala Nya Tidning)

We believe that there is demand for more plannable electricity production, that is, production which is not weather dependent. As of today, no expansion plans for such production exist and that is a problem. (Sverige kan bli mer sårbart vintertid, TT)

The centralized narrative strongly emphasizes the severe economic ramifications that an electricity shortage would cause. The foremost consequence being presented is impeded economic growth on both regional and national levels. This line of reasoning is built around the assumption that Sweden's prosperity is founded upon the success of its large industries-timber, chemistry, mining and steel. These industries are considered the economic engines of the state. Obstructing their operations would evidently have dire outcomes for the nation's wealth, such as loss of tax revenue and job opportunities.

The worries about losing control over the electricity supply are also reflected in the centralized narrative's attention to electricity prices. Soaring prices are expected as a result of an electricity shortage and increasing the ratio of intermittent renewable energies is said to inflate the prices even further. The conclusion that follows is that the only safeguard against volatile energy prices is a stable electricity system where the source of electricity can be controlled, namely nuclear power.

Less prominent, yet present, is the claim that an electricity shortage will hinder sustainable development. For example, the electrification of the transport sector will require a higher electricity output, and a failure to accommodate this transition will prolong the dependency on fossil fuels.

Most solutions presented within the centralized narrative strive to regain control over the electricity supply. To achieve this, the current nuclear power production should be saved, either by removing existing taxation or through subsidies. Some solutions are yet more progressive and propose expanding nuclear power production by building next-generation facilities.

The idea of nuclear power as a panacea belongs to the most distinguished opinion of the centralized narrative. However, within the narrative there also exists another branch in the sense that its ideas rely less on nuclear power and more on renewable energy and international collaborations as solutions. What sets the opinions apart is their definition of the problem. Whereas the former believes electricity shortage to be an issue of production, the latter regards it as a matter of poor infrastructure. 
Sweden produces sufficient electricity, but the power grid cannot meet the growing demand from densely populated areas. Electronic vehicles, new residential areas and digitalization have increased the electricity demand while the grid has seen no improvements in several years. (Elnätet räcker inte till-byggprojekt kan stoppas, Dagens Nyheter)

Naturally, their solutions also differ accordingly. However, although they disagree on the cause of the problem and its reconciliation, they have a shared ideology. What connects them is the common idea of a centralized electricity system and their belief in the state.

The hero in the centralized narrative is "the state". The state is perceived as the solid foundation upon which the electricity system should be built. The desire for a stable and controllable system is projected onto the state, which in this regard symbolizes and is equated with stability. It is perceived as the obligation of the state to cater to the electricity demand of the nation and the state is deemed the sole actor with this capacity. The state provides economic resources, governs the energy market and facilitates its development. However, the government is also cast as villain in the centralized narrative. The government is almost unanimously held accountable for the electricity shortage and is to be blamed for lack of investment in power production and infrastructure. This conviction corresponds with the typology of Lönnroth et al. [36] where accountability is centralized and public. Large corporations and the industry are conceived as victims of the government's irresponsibility. Due to the government's negligence in providing them with the electricity they require, they are unable to grow and profit accordingly. This obstruction is deemed a tragedy, not only for business, but also for the nation. Local distribution system operators are also considered victims of the poor governance of the government, as they are unable to accommodate their customers' needs. Lastly, the citizens are also viewed as victims as they are exposed to the risk of blackouts.

Supporters of the centralized narrative constitute the Swedish government, umbrella business organizations, the industry and the media. Among the political parties, the Moderate Party is the strongest supporter. The Moderate Party is a conservative party and the largest political party in Sweden, second only to the Social Democratic Party. They are also the largest party in the opposition. The Swedish transmission system operator and privately owned multinational energy companies are the actors among energy companies that are the strongest supporters of the centralized narrative. Worthy of mention is the narrative's lack of emphasis on a distinct future vision of the electricity system, which is likely a result of the opinion that the future system should resemble the present.

\section{The decentralized narrative}

The decentralized narrative is almost exclusively intertwined with ideas of sustainable development. The adherents of this narrative emphasize transformation of the electricity system, expansion of renewable energy generation share, and flexible electricity consumption and production. A prominent theme within the narrative is also collaboration and cooperation between the public and private sectors on local, regional and national levels.

Society is changing and so is the electricity system. (...) Future electricity demand is not met by increased production solely, but through societal collaborations, including large industries and private consumers, to create a more efficient and flexible electricity consumption. (Storstäderna måste producera el lokalt, Dagens Industri)

I believe that the situation compels us to reassess the notion that we must build more power plants whenever we reach a capacity peak. (Lågt elpris I tio år till, Dagens Industri)

The electricity shortage, according to the decentralized narrative, is an issue of an outdated system. Although acknowledging that the electricity system has served Sweden well, the adherents claim that it is backward and not adapted to contemporary needs and conditions. The evolution of the electricity system has not kept pace with the progression of electricity demand, which now has resulted in an electricity shortage. Thus, the electricity shortage is not considered the problem but rather a symptom of it. Ultimately, the plan is not only to solve the electricity shortage but also to transform the power grid into a sustainable electricity system.

The decentralized narrative is part of the sustainable development discourse, with the focus on creating resilience and finding remedies for climate change. The consequences of neglecting to tackle the problem will, therefore, result in unachieved climate goals, which is also the primary argument for a decentralized system that the narrative conveys. For example, the increasing electrification of several sectors, i.e., moving away from fossil fuel dependency, is argued to require a more flexible system. Similar to the centralized narrative, impaired sustainable transformation is also regarded as a consequence. 
The decentralized narrative is to a large extent driven by innovation and new technology. Several of the solutions put forward relate to technological improvements. The most prominent idea is the decentralized electricity system, meaning an electricity system constituting several smaller electricity producers instead of a few large power plants. The narrative depicts a future where energy from local and regional wind and hydropower plants is complemented with energy from privately and communally owned solar cells. In this vision, the consumers are also the producers.

The electricity system must be adjusted to several smaller production facilities instead of a few large. Currently, the system is constructed around nuclear power production. (Det förnybara är framtiden, Dagens ETC)

We are moving toward a society where consumers become micro producers. The large power plants are still needed to secure the energy supply, but a majority of the expansion will happen in small-scale and renewable production. (Kollaps hotar elsystemet, Dagens Industri)

Great emphasis is also placed on substituting fossil fuel-intense energy sources with renewable energy. However, increasing the share of wind, hydro and solar power will also create new preconditions, as this type of electricity production is weather dependent. Such an electricity system will require greater flexibility, which is also the strongest theme within the narrative's solutions. In this context, flexibility refers to adjusting consumption according to the electricity available at any given moment. By consuming electricity "smarter", the consumption will not only be divided more evenly throughout the day, but the overall consumption will also be reduced. This idea also ties into another of the proposed solutions, namely smart grids.

Smart grids may be understood as "the overlaying of a unified communications and control system on the existing power delivery infrastructure to provide the right information to the right entity" [49]. In doing so, smart grids integrate advanced sensing technologies, the Internet of Things, big data and AI [50], thus constructing a system of systems [51]. However, a smart grid is not any particular technology, but is rather defined by its functions and abilities [52]. In the decentralized narrative, the emphasis is on enabling electricity consumers to change their consumption patterns by installing smart meters. In doing so, consumers will gain control over their usage. Emphasis is also on the bidirectional communication in smart grids, which enables redistribution of electricity to where it is needed the most and energy storage.

The idea of decentralization as a solution extends beyond the physical components of the grid. The decentralized narrative also advocates decentralized governance. Corresponding to the typology by Lönnroth et al. [36], the decentralized narrative depicts a form of energy governance where electricity production is a joint process by municipal institutions, in collaboration with industries, local facilities and neighborhoods.

Society is depicted as the hero in this narrative, meaning that no actor can single-handedly solve the electricity shortage. The challenge requires a joint effort and will include a variety of stakeholders, such as municipalities, local energy producers, entrepreneurs, academia, etc. In that sense, every stakeholder is a hero in this narrative. Thus, society as a whole constitutes the force that will transform the electricity system. Similarly, the decentralized narrative has an undefined villain, although the government is held accountable for not accommodating the collaboration accordingly. However, the narrative strongly emphasizes the individual responsibility of each stakeholder. Every stakeholder is thus also a potential villain should they not participate. As aforementioned, the electricity shortage is perceived as only the symptom of the problem. The real problem is the development and the future of the electricity system. Consequently, the victim of this narrative is the "future" society, which will suffer should the contemporary society fail to transform the electricity system.

Supporters of the decentralized narrative comprise academia, energy consultants, umbrella energy organizations, and NGOs. Among the political parties, the Green Party is the most prominent supporter. The prominence of a future vision in the narrative is likely a result of the nature of the solutions it proposes. The narrative promotes solutions that are yet to be realized, and it consequently expresses more a distinguished future vision for the electricity system. As it argues for overturning the current structure of the present system, it must depict a clear alternative. The society is likely depicted a hero as the narrative is dependent on a joint effort for realizing its vision. Correspondingly, it threatens the society by depicting it as a victim should it omit to transform the electricity system.

\section{Discussion}

\section{The ramifications of centralized systems thinking}

The analysis showcased that there is a clear dominance of the centralized narrative in the media discourse. Whether its content actually reflects the ideas and opinions of policy-makers is still to be determined. Nevertheless, the results indicate that the prevailing 
centralized thinking may constitute a barrier for solving the electricity shortage problem as well as for integrating new technologies and transforming the electricity system toward a more sustainable path. This issue is accentuated when viewed through transition theory [53, 54]. Using this analogy, the paradigm constitutes the electricity system and the regime comprises the system's centralized design, i.e., the aggregation of electricity production technology, infrastructure, engineering practices, expertise, knowledge and consumer behavior. The success of any niche, which in this instance would be a decentralized electricity system, is dependent on whether it can co-exist with the regime. However, similar to the ways in which large technical systems hinder new technology from entering [40-43], the regime poses a barrier and thus prevents any niche from gaining traction [55]. In essence, the dominance of centralized thinking in the public discourse is problematic, as it risks overlooking the many benefits of a decentralized electricity system. The remainder of this section will elaborate on these benefits and the ramifications of ignoring them.

Firstly, decentralized electricity systems are by some promoted as an efficient, reliable and green alternative to the conventional electricity system $[37,46,56]$. This is in part due to the nature of renewable energy generation, which will likely require a modification of the structure of the electricity system toward decentralization [44], as decentralized systems are better suited to accommodate renewable energy technologies $[56,57]$. However, it should also be noted that different examples from Europe have showcased that the introduction of renewable energy technologies for electricity can be achieved using both centralized and decentralized pathways $[1,58]$.

Secondly, the factors determining whether an electricity system is centralized or decentralized are, as aforementioned, not only limited to the geographical proximity and scale of the electricity production and the conversion units. Both centralization and decentralization comprise aspects of politics, administration, finance and business [1,37]. The decentralization of the electricity system thus to some extent implies a democratization of the system, as the decision-making, the responsibility, the ownership, and the economy of the electricity system to some degree become localized $[59,60]$. In other words, decentralization may entail a greater level of energy democracy. However, it should be noted that this assumption cannot be taken for granted in every instance [45]. Nevertheless, ignoring this benefit by promoting centralized governance risks excluding actors that otherwise may contribute to solutions.

Thirdly, the local nature of decentralized electricity systems has in theory been associated with several positive environmental and societal effects. The close proximity of electricity production and conversion units will require fewer transmission lines, which in turn implies fewer transmission losses. It is also assumed that having more control over electricity production and consumption will result in a more conscious and efficient resource use, thereby also reducing the environmental impact. Furthermore, it is also assumed that localization will also entail new job opportunities [37]. This is however yet to be scientifically verified $[61,62]$.

The fourth advantage of decentralized systems relates to their higher degree of flexibility. A system with large system units is very efficient in regard to decision-making, expertise and knowledge, but is also very slow-moving and inflexible due to its scale. The scale also renders it more open to risk. In contrast, a system with small units disperses the risk due to its high level of flexibility [37]. Decentralized electricity systems are also more flexible in terms of scalability. Adding smaller facilities to a decentralized system is in all likelihood more feasible than building large and centralized power plants in regard to time, effort and costs. This also entails that as technology advances, replacing old units will be faster and less expensive in decentralized systems $[37,56]$. Additionally, decentralized systems are more flexible in a third regard, namely flexibility in reaction to price fluctuations, which renders them a protective hedge against high electricity prices [56].

The fifth advantage often mentioned in relation to decentralized systems concerns the accommodation of a growing demand for electricity, due to increasing electrification and urbanization. Rather than building more power plants and larger transmission lines, research suggests that solutions should be sought in decentralized technologies. In comparison with investments in the transmission and distribution lines of centralized systems, decentralized electricity system units are faster and less expensive to implement and could be a seamless substitute for the former $[56,57]$. Insisting on a centralized system thus risks overlooking potentially cheaper alternatives and new business models for solving the electricity shortage.

In summary, several aspects of the decentralized electricity system were neglected in the media discourse. In comparison, the positive aspects of the existing centralized system were highlighted to a larger extent. Considering the above-mentioned advantages of decentralized electricity systems, along with the notion that media contributes to envisioning the energy future [26], there would be several societal benefits were the electricity shortage in Sweden to be addressed in a more decentralized manner. However, a complete decentralization of the electricity system as a remedy for all its ills is neither 
likely nor desirable. Solutions should rather seek to combine the benefits of both centralized and decentralized electricity systems. The optimum would be if the two systems could exist and operate alongside each other [37, 44].

\section{Lock-in and system change resistance}

Having too narrow a focus when seeking solutions to the electricity shortage not only risks overlooking better options but may also result in a technological lock-in. Lock-in is a self-reinforcing mechanism based on the understanding of how contemporary decisions will determine future actions [63]. The adaptation of new technology is dependent on existing socio-technical systems' standards and architectures. Consequently, when new technology is introduced, it not only reinforces the dominance of the existing system but it also locks the system into a certain path of development $[63,64]$. From this follows that the more mature a socio-technical system is, the more entrenched its path of development will be. Furthermore, this entrenchment creates a resistance toward technology that is incompatible with existing structures. As a result, a socio-technical system may favor outdated technology over technology with potentially better performance [63]. Once a system is firmly established, it will likely result in a lock-in, as it is both costly and difficult to diverge from the current path of development. This is particularly evident in systems with technology that has a long life expectancy [64].

The dominance of the centralized narrative may in part be explained by an evolving technological lock-in. Another explanation can be found in the work of Kaijser et al. [65]. They argue that large-scale socio-technical systems are guided by dynamics that constantly safeguard and consolidate the system's position of power. In other words, technological innovations and solutions that enhance the system will perpetually be favored over innovations or solutions that challenge it. Consequently, every solution sought supports the system's continued existence. Through its established position, the system may thus also counteract and prevent the development of technical solutions that are not within the system's framework [40-43]. This safeguarding mechanism of socio-technical systems might constitute another explanation for the centralized narrative's strong position.

The centralized narrative intertwines nuclear power production with a centralized electricity system. These two are to some extent synonymous to the supporting actors of the narrative. The support for a centralized electricity system should thus also be understood as an act in defense of nuclear power production. Due to the strong symbology of Swedish nuclear power production [48], questioning the idea of new and/or sustained nuclear power production is interpreted as an attack on the on the industry's right to growth, and ultimately an attack on the system that enabled the creation of the welfare state. However, the arguments used are far from novel. When contemporary nuclear power proponents claim that the decommissioning of nuclear power production constitutes a threat to job opportunities, low electricity prices, and regional and economic growth, they join a long tradition of thought dating back to the 1950s. As explained in the historical account by Anshelm [48], the arguments in favor of nuclear power production have remained the same over the years and have reoccurred in decadal cycles, albeit in updated forms.

However, since the pledge by the Swedish government to a $100 \%$ share of renewables in energy production by 2040, a new argument for nuclear power production has been added to the repertoire. To include nuclear power within that goal, the political Right demands that the phrasing of the policy should be changed; instead of "renewable" the policy should read "fossil free". The difference might appear minor at first glance, but such change would allow for a continuation of nuclear power production. And considering that nuclear power production constitutes $40 \%$ of the Swedish energy baseload, such rephrasing would have substantial implications for a transformation of the electricity system. This constitutes a very clear example of how a system is resisting change, as described by Kaijser et al. [65].

\section{Implications for energy policy}

Highlighting the dominance of the centralized narrative is of significance for policy-makers and for the industry, as there will be a number of implications should the centralized ideas receive too much attention and gain too much traction. These implications concern both the solutions to the electricity shortage and the future development of the electricity system.

The first implication relates to the content of the centralized narrative. The narrative presents a very simplified understanding of the origin of the electricity shortage, its consequences, and potential remedies. Consequently, the solutions it proposes will be ineffective and expensive in the long-term. The narrative's primary concern is economic growth; environmental considerations are often secondary. The centralized narrative deems that the government should be held accountable for the electricity shortage. This narrow focus in finding a single scapegoat overlooks how other actors could contribute. Concurrently, the decentralized narrative suffers from a lack of a clear strategy for upholding accountability. The decentralized narrative fails to recognize that the many actors involved in a decentralized electricity system and its lack of monopolistic hierarchy in decision-making will require a high level of contracting [66-68]. 
The second implication concerns how the simplified understanding of the centralized narrative risks nurturing narrowly focused solution thinking in the minds of policy-makers. This would in turn result in overlooking the many advantages of a decentralized electricity system. Finding the solution to the electricity shortage in decentralized systems thinking would not only render less expensive options, but also potentially contribute to increased levels of energy democracy, a higher degree of flexibility, decreased environmental impact of the electricity system, and a system better suited for future challenges and sustainable development.

The third implication refers to how a one-sided understanding of a technological problem risks creating a lock-in. The ramification of only focusing on a single technological orientation is a system that favors outdated technology over technology with potentially better performance. The longer such technological developments proceed unabated, the more costly it will be to sustain the system. Applied to the Swedish context, such development would also contribute to rendering the electricity system ill-equipped to cope with future electricity shortages as well as other challenges. The one-sided understanding of the problem is at the same time to some extent valid for the decentralized narrative. Rather than emphasizing innovation and new technology, it should instead focus on finding solutions for integration and progression within the existing system.

Lastly, the centralized narrative's protectionist attitude toward nuclear power production risks cultivating the idea that nuclear power should be favored over other technologies. Although nuclear power is considered to aid in the decarbonization of electricity production, it is also widely held that the operation of nuclear power plants is associated with risks and that they are ill-suited for electricity systems with a large share of flexible and renewable energy generation [57]. Ultimately, such a protectionist attitude may stall a transformation of the electricity system and result in an outdated system unfit to cope with future challenges.

\section{Conclusion}

This study set out to answer the question of how the future of Sweden's electricity system in general and the electricity shortage in particular has been discussed and envisioned within Swedish media discourse over the last decade. The analysis showcased that two competing narratives have been figuring in the debate-the centralized and the decentralized narrative. The centralized narrative argues for remedying the electricity shortage by building more power plants and making large investments in the electricity infrastructure, whereas the decentralized narrative asserts that the problem should be solved through decentralization and by creating a more flexible electricity system. The narratives also hold visions of Sweden's energy future, which to a large extent shape each narrative's understanding of the electricity shortage and its reconciliation. The centralized narrative imagines a continuation of the current centralized structure of the electricity system; that is, an electricity system dominated by a few very large actors and where the governance and accountability are centralized. The decentralized narrative, on the other hand, envisages a decentralized electricity system where the production is localized and with a much larger share of renewable energy generation. Governance and accountability are divided among actors on local, regional and national levels.

Media discourses are instrumental in the process of shaping and reproducing narratives and future visions. They influence the perception of what the future will look like [26]. This notion adds weight to this study, which has shown that the media discourse has overwhelmingly been dominated by the centralized narrative. The predominance of the centralized narrative may be understood as an act of safeguarding and defending the current electricity system from change. Furthermore, the centralized narrative intertwines nuclear power production with the centralized structure of the electricity system. These two are to some extent synonymous with the supporting actors of the narrative. The historical significance of nuclear power production might also explain its prominence in the centralized narrative.

This study has highlighted a number of implications for policy-makers and for the industry that may surface should the centralized narrative receive too much attention in energy policy:

1. The centralized narrative presents a very simplified understanding of the origin of the electricity shortage, its consequences, and potential remedies, as well as future challenges for the electricity system. Relying on the centralized narrative as a source of knowledge will likely result in a lack of understanding of the true nature of the problem.

2. The simplified understanding of the centralized narrative risks nurturing narrowly focused solution thinking. This would in turn result in overlooking the many advantages of a decentralized electricity system. Finding the solution to the electricity shortage in decentralized systems thinking would not only render less expensive options, but also contribute to increased levels of energy democracy, a higher degree of flexibility, and decreased environmental impact of the electricity system.

3. The prevalence of the idea of a centralized electricity system risks creating a technological lock-in. Failing 
to recognize other options as viable will entrench the path of development. The ramification of only focusing on a single technological orientation is a system that favors outdated technology over technology with potentially better performance. The longer such entrenched technological development proceeds, the more costly it will be to sustain it.

4. Upholding a centralized strategy will likely result in an outdated electricity system and may prevent the electricity system moving onto a more sustainable trajectory.

Considering the above-mentioned potential implications should the centralized narrative gain too much traction, along with the notion that media plays a significant role in envisioning the energy future [26], there would be several societal benefits if the challenges facing the electricity system were addressed in a more decentralized manner. However, a complete decentralization of the system as a remedy for all its ills is neither likely nor desirable. Solutions should rather seek to combine the benefits of both centralized and decentralized electricity systems $[37,44]$.

In a concluding note, this study proposes that more research in this area may reveal to what extent the narratives actually influence decision-making in energy policy in Sweden and worldwide. Another possible avenue for future research is to conduct complementary studies for comparison. For example, the ongoing debate in the EU constitutes an interesting case as it emphasizes energy communities to a greater extent.

\section{Acknowledgements}

The research has received funding from Energimyndigheten project $\mathrm{nr}$ 47811-1 and in the framework of the joint programming initiative ERA-Net Smart Energy Systems, with support from European Union Horizon 2020 research and innovation program under Grant agreement No. 775970.

\section{Authors' contributions}

The entire article is the contribution of Frans Libertson. The author read and approved the final manuscript.

\section{Funding}

Open Access funding provided by Lund University. The research has received funding from Energimyndigheten project nr 47811-1 and in the framework of the joint programming initiative ERA-Net Smart Energy Systems, with support from European Union Horizon 2020 research and innovation program under Grant agreement No. 775970.

\section{Availability of data and materials}

The datasets generated and analyzed during the current study are available in the Retriever Research repository, which was accessed via Lund University. http://ludwig.lub.lu.se/login?url=http://web.retriever-info.com.ludwig.lub. lu.se/services/archive.html.

Ethics approval and consent to participate Not applicable.

\section{Consent for publication}

Not applicable.

\section{Competing interests}

The author hereby declares that no competing interests exist.

Received: 10 September 2020 Accepted: 29 January 2021

Published online: 18 February 2021

\section{References}

1. Hojčková K, Sandén B, Ahlborg H (2018) Three electricity futures: monitoring the emergence of alternative system architectures. Futures 98:72-89

2. International Energy Agency (2019) Key electricity trends 2019_analysis. In: IEA. https://www.iea.org/articles/key-electricity-trends-2019. Accessed 9 July 2020

3. Pinson P, Baroche T, Moret F, Sousa T, Sorin E, You S (2017) The emergence of consumer-centric electricity markets. Distrib Util 34:27-31

4. Fuchs $\mathrm{G}$, Hinderer N (2014) Situative governance and energy transitions in a spatial context: case studies from Germany. Energy Sustain Soc 4:1-11

5. Markard J, Geels FW, Raven R (2020) Challenges in the acceleration of sustainability transitions. Environ Res Lett 15:081001

6. EU-Commission (2009) Mobilising Information and Communications Technologies to facilitate the transition to an energy-efficient, lowcarbon economy

7. Liebensteiner M, Wrienz M (2020) Do intermittent renewables threaten the electricity supply security? Energy Econ 87:104499

8. Mateo C, Frías P, Cossent R, Sonvilla P, Barth B (2017) Overcoming the barriers that hamper a large-scale integration of solar photovoltaic power generation in European distribution grids. Sol Energy 153:574-583

9. Swain RB, Karimu A (2020) Renewable electricity and sustainable development goals in the EU. World Dev 125:104693

10. Nystrand M (2020) \#Uppsalaeffekten - en beskrivning av hur samhället gick samman för att fixa kapacitetsutmaningarna i elsystemet

11. Taljegård M (2019) Electrification of road transportation-implications for the electricity system. PhD thesis, Chalmers Tekniska Hogskola (Sweden)

12. Velkova J (2016) Data that warms: waste heat, infrastructural convergence and the computation traffic commodity. Big Data Soc 3:205395171668414. https://doi.org/10.1177/2053951716684144

13. Vonderau $A$ (2018) Scaling the cloud: making state and infrastructure in Sweden. Ethnos. https://doi.org/10.1080/00141844.2018.1471513

14. Svenska Kraftnät (2018) Kraftbalansen på den svenska elmarknaden, rapport 2018

15. International Energy Agency (2019) Energy policies of IEA countriesSweden 2019 review. International Energy Agency, Paris

16. Svenska Kraftnät (2017) SYSTEM DEVELOPMENT PLAN 2018-2027

17. Byman K, Koebe C, Ingenjörsvetenskapsakademien (2016) Sveriges framtida elproduktion: en delrapport: IVA-projektet Vägval el. Kungl. Ingenjörsvetenskapsakademien (IVA), Stockholm

18. Energimarknadsinspektionen (2020) Kapacitetsutmaningen i elnäten. Energimarknadsinspektionen

19. Tidwell JH, Tidwell AS (2018) Energy ideals, visions, narratives, and rhetoric: examining sociotechnical imaginaries theory and methodology in energy research. Energy Res Soc Sci 39:103-107

20. Jasanoff S, Kim S-H (2009) Containing the atom: sociotechnical imaginaries and nuclear power in the United States and South Korea. Minerva 47:119. https://doi.org/10.1007/s11024-009-9124-4

21. Mohan A, Topp K (2018) India's energy future: contested narratives of change. Energy Res Soc Sci 44:75-82. https://doi.org/10.1016/j. erss.2018.04.040

22. Ballo IF (2015) Imagining energy futures: sociotechnical imaginaries of the future Smart Grid in Norway. Energy Res Soc Sci 9:9-20. https://doi. org/10.1016/j.erss.2015.08.015

23. Leipprand A, Flachsland C, Pahle M (2017) Advocates or cartographers? Scientific advisors and the narratives of German energy transition. Energy Policy 102:222-236. https://doi.org/10.1016/j.enpol.2016.12.021

24. Kuchler M, Bridge G (2018) Down the black hole: sustaining national socio-technical imaginaries of coal in Poland. Energy Res Soc Sci 41:136-147. https://doi.org/10.1016/j.erss.2018.04.014

25. Mullally G, Byrne E (2015) A tale of three transitions: a year in the life of electricity system transformation narratives in the Irish media. Energy Sustain Soc 6:1-14 
26. Hielscher S, Sovacool BK (2018) Contested smart and low-carbon energy futures: media discourses of smart meters in the United Kingdom. J Clean Prod 195:978-990. https://doi.org/10.1016/j.jclepro.2018.05.227

27. Robison R, Skjølsvold TM, Lehne J, Judson E, Pechancová V, Foulds C, Bilous L, Büscher C, Carrus G, Darby S (2020) 100 Social sciences and humanities priority research questions for smart consumption in Horizon Europe. Energy-SHIFTS, Cambridge

28. Skjølsvold TM (2012) Curb your enthusiasm: on media communication of bioenergy and the role of the news media in technology diffusion. Environ Commun J Nat Cult 6:512-531

29. Levidow L, Papaioannou T (2013) State imaginaries of the public good: shaping UK innovation priorities for bioenergy. Environ Sci Policy 30:36-49

30. McBeth MK, Shanahan EA, Jones MD (2005) The science of storytelling: measuring policy beliefs in Greater Yellowstone. Soc Nat Resour 18:413-429. https://doi.org/10.1080/08941920590924765

31. Hermwille $L$ (2016) The role of narratives in socio-technical transitionsFukushima and the energy regimes of Japan, Germany, and the United Kingdom. Energy Res Soc Sci 11:237-246. https://doi.org/10.1016/j. erss.2015.11.001

32. Leach M, Scoones I, Stirling A (2010) Governing epidemics in an age of complexity: narratives, politics and pathways to sustainability. Glob Environ Change 20:369-377. https://doi.org/10.1016/j.gloenvcha.2009.11.008

33. McComas K, Shanahan J (1999) Telling stories about global climate change: measuring the impact of narratives on issue cycles. Commun Res 26:30-57. https://doi.org/10.1177/009365099026001003

34. Delina LL (2018) Whose and what futures? Navigating the contested coproduction of Thailand's energy sociotechnical imaginaries. Energy Res Soc Sci 35:48-56

35. Patterson M, Monroe KR (1998) Narrative in political science. Annu Rev Polit Sci 1:315-331. https://doi.org/10.1146/annurev.polisci.1.1.315

36. Lönnroth M, Johansson TB, Steen P, Johanson KE (1978) Sol eller uran: att välja energiframtid: [slutrapport från projektet Energi och samhälle]. LiberFörlag

37. Alanne K, Saari A (2006) Distributed energy generation and sustainable development. Renew Sustain Energy Rev 10:539-558

38. Bhadoria VS, Pal NS, Shrivastava V (2013) A review on distributed generation definitions and DG impacts on distribution system. In: Proc int conf advanced computing and communication technologies (ICACCT $\left.{ }^{\mathrm{TM}}-2013\right)$, pp 1-5

39. Quezada G, Grozev G, Seo S, Wang C-H (2014) The challenge of adapting centralised electricity systems: peak demand and maladaptation in South East Queensland, Australia. Reg Environ Change 14:463-473

40. Palm J (2006) Development of sustainable energy systems in Swedish municipalities: a matter of path dependency and power relations. Local Environ 11:445-457

41. Coutard O (2002) The governance of large technical systems. Routledge, Abingdon

42. Mayer M, Acuto M (2015) The global governance of large technical systems. Millennium 43:660-683

43. Mayntz R, Hughes T (2019) The development of large technical systems. Routledge, Abingdon

44. Funcke B (2016) Typology of centralised and decentralised visions for electricity infrastructure. Util Policy 40:67-74

45. Judson E, Fitch-Roy O, Pownall T, Bray R, Poulter H, Soutar I, Lowes R, Connor PM, Britton J, Woodman B (2020) The centre cannot (always) hold: examining pathways towards energy system de-centralisation. Renew Sustain Energy Rev 118:109499

46. Ackermann T, Andersson G, Söder L (2001) Distributed generation: a definition. Electr Power Syst Res 57:195-204

47. El-Khattam W, Salama MM (2004) Distributed generation technologies, definitions and benefits. Electr Power Syst Res 71:119-128

48. Anshelm J (2000) Mellan frälsning och domedag: om kärnkraftens politiska idéhistoria i Sverige 1945-1999. B. Östlings bokförl. Symposion

49. Siddiqui O, Hurtado P, Parmenter K (2008) The green grid: energy savings and carbon emissions reductions enabled by a smart grid
50. Koohi-Kamali S, Tyagi VV, Rahim NA, Panwar NL, Mokhlis H (2013) Emergence of energy storage technologies as the solution for reliable operation of smart power systems: a review. Renew Sustain Energy Rev 25:135-165. https://doi.org/10.1016/j.rser.2013.03.056

51. Camarinha-Matos LM (2016) Collaborative smart grids-a survey on trends. Renew Sustain Energy Rev 65:283-294. https://doi.org/10.1016/j. rser.2016.06.093

52. Hashmi M, Hänninen S, Mäki K (2011) Survey of smart grid concepts, architectures, and technological demonstrations worldwide. In: 2011 IEEE PES conference on innovative smart grid technologies Latin America (ISGT LA), pp 1-7

53. Geels FW (2002) Technological transitions as evolutionary reconfiguration processes: a multi-level perspective and a case-study. Res Policy 31:1257-1274

54. Geels FW, Schot J (2007) Typology of sociotechnical transition pathways. Res Policy 36:399-417

55. Markard J, Truffer B (2006) Innovation processes in large technical systems: market liberalization as a driver for radical change? Res Policy 35:609-625. https://doi.org/10.1016/j.respol.2006.02.008

56. Pepermans G, Driesen J, Haeseldonckx D, Belmans R, D'haeseleer W (2005) Distributed generation: definition, benefits and issues. Energy Policy 33:787-798

57. Bruckner T, Bashmakov IA, Mulugetta Y, Chum H, De la Vega Navarro A, Edmonds J, Faaij A, Fungtammasan B, Garg A, Hertwich E (2014) Energy systems. In: Edenhofer O, Pichs-Madruga R, Sokona Y, Farahani E, Kadner S, Seyboth K, Adler A, Baum I, Brunner S, Eickemeier P, Kriemann B, Savolainen J, Schlömer S, von Stechow C, Zwickel T, Minx JC (eds) Climate change 2014: mitigation of climate change. Contribution of working Group III to the fifth assessment report of the intergovernmental panel on climate change. Cambridge University Press, Cambridge

58. Funcke R-W (2020) Storylines of (de) centralisation: exploring infrastructure dimensions in the German electricity system. Renew Sustain Energy Rev 121:109652

59. Van Veelen B (2018) Negotiating energy democracy in practice: governance processes in community energy projects. Environ Polit 27:644-665

60. Walker G, Devine-Wright P (2008) Community renewable energy: what should it mean? Energy Policy 36:497-500

61. Hicks J, Ison N (2018) An exploration of the boundaries of 'community' in community renewable energy projects: navigating between motivations and context. Energy Policy 113:523-534

62. van der Grijp N, Petrovics D, Roscoe J, Barnes J, Blasch J, Darby S, Golob U, Palm J (2019) Theoretical framework focusing on learning in polycentric settings

63. Markusson N, Haszeldine S (2009) 'Capture readiness'-lock-in problems for CCS governance. Energy Procedia 1:4625-4632. https://doi. org/10.1016/j.egypro.2009.02.284

64. Davies A (1996) Innovation in large technical systems: the case of telecommunications. Ind Corp Change 5:1143-1180. https://doi. org/10.1093/icc/5.4.1143

65. Kaijser A, Steen P, Mogren A (1988) Att ändra riktning : villkor för ny energiteknik, 1. uppl. Allmänna förl

66. Considine M (2005) Making public policy: institutions, actors, strategies. Polity

67. Dicke LA, Ott JS (1999) Public agency accountability in human services contracting. Public Product Manag Rev 22:502-516

68. Palm J (2008) Emergency management in the Swedish electricity market: the need to challenge the responsibility gap. Energy Policy 36:843-849

\section{Publisher's Note}

Springer Nature remains neutral with regard to jurisdictional claims in published maps and institutional affiliations. 